\title{
THE APPLICATION OF MATHEMATICAL MODELS IN MANAGEMENT OF AQUIFER
}

\author{
Khosrow Shafiei Motlagh and Samad zahermand \\ Department of Civil Engineering, Dehdasht Branch, \\ Islamic Azad University, Dehdasht, Iran
}

\begin{abstract}
Before feeling water-shortage crisis human has understood the importance of water From the religious texts. Considering recent conditions of the world the water will replace most recent boundaries, at future. Imamzadeh Jaafar plain is located 5 kilometers northeast of Gachsaran, south of Kohgilooye and Boerahmad province. The plain has $61 \mathrm{~km} 2$ area extents and contains two, alluvial and carbonate aquifers. These aquifers supply the water needs, agricultural, industrial and domestic. Highly exploitation and transportation of groundwater resources, especially by National Oil Company, caused highly drawdown in alluvial aquifer, $1.85 \mathrm{~m}$ in a 5 years period from 1361 to 1365 as reported by Mahab Ghods Consulting Engineers. There are two artificial recharge projects, 1 flood spreading system and 1 recharge ponds system, in the plain. To present the future water resources management program the hydrogeological behaviors of the alluvial aquifer and the effects of artificial recharge must be evaluated. edrock, hydrodynamic coefficients, topography, water resources and were collected, field surveys were performed and required maps were prepared. Using conceptual model and MODFLOW PMWIN code the mathematical model of the plain was calibrated against water year $1380-81$ and then verified against water year 1384-85. The verified model was used to predict future conditions of aquifer. The results implied the rapid response of aquifer to precipitation due to high aquifer ransmissivity, positive water budget at year 1385 comparing year 65, change of direction of groundwater flow from plain outlet to the center of plain in response to highly exploitation at the center of plain, water level in the wells located downward the flood spreading system will raise as 1 to $6 \mathrm{~m}$ and water level in the wells located downward the recharge pond system will lower as 1 to $4 \mathrm{~m}$.
\end{abstract}

\section{KEYWORDS}

Ground water, MODFLOW PMWIN, artificial recharge, Kohgilooye \&Boerahmad.

\section{INTRODUCTION}

Groundwater models are often developed to obtain predictions of societal importance. Such predictions might be the response of an aquifer to future groundwater pumping, or the groundwater transport of contaminants from a source location. Because the groundwater flow system characteristics represented in such models are always unknown to some degree, model predictions are uncertain. To reduce this prediction uncertainty, it is necessary to improve the model so that it more accurately represents the flow system. However, groundwater models often represent extremely complex hydrologic and hydrogeological conditions, and because field

DOI: $10.5121 / \mathrm{ams} .2018 .5101$ 
Advanced Medical Sciences: An International Journal (AMS), Vol 5, No.1, February 2018

characterization of these conditions can be costly and time consuming, it is rarely feasible to improve the representation of all aspects of a simulated system. Thus it is of interest to identify the particular attributes of a flow system that are most important to the relevant predictions, and to focus field characterization on these attributes.In this paper, this problem is addressed by determining the model parameters that are most important to the predictions. Identification of these parameters can help guide collection of two types of hydrogeological data that are likely to improve the predictions. First, information can be collected about the values of the important parameters. Field activities to obtain this type of data include, for example, hydraulic tests for estimating transmissivity and storability values. Second, data can be collected about features of the flow system that are related to the important parameters, such as the geometry and internal variability of a hydrogeological unit associated with a hydraulic conductivity parameter. Field activities might include geologic and geophysical investigation and interpretation of the extent and thickness of the hydrogeological unit. Relevance of the proposed method to the second data type assumes a link between model parameter importance and flow system feature importance. We recognize that the parameters identified as most important to the model predictions may not always correspond to the features of model construction that are most important to the model predictions, but it is expected that there will often be such a correspondence.In the hydrologic literature, a number of procedures have been developed for improving model accuracy in the context of model predictions. One body of work focuses on collection of additional observations or targets used to calibrate a model, such as hydraulic heads, flows, and concentrations [e.g., Loaiciga, 1989; Sun and Yeh, 1990; Wagner, 1995; Ely et al., 2000; Hill et al., 2001]. Approaches more closely related to the work presented in this paper are those that address the collection of direct information about flow system characteristics or about hydrogeologic property values, for the purpose of improving model predictions. These approaches can be divided into two broad groups. The first group includes methods for identifying important locations for additional aquifer property measurements [e.g., McLaughlin and Wood, 1988; McKinney and Loucks, 1992; Sun and Yeh, 1992]. In these studies, the simulated hydraulic conductivity fields are estimated from point measurements by some variation of kriging. Inclusion of new hydraulic conductivity measurements reduces the estimation variance of the kriged hydraulic conductivity field, which in turn reduces prediction uncertainty.Kohgiloyeh and Boerahmad province located in southwestern Iran, which is having nearly one percent of the total area of the iran country is allocated to, an average annual rainfall of $720 \mathrm{~mm}$ and $7 / 11$ billion cubic meters of precipitation. Imam Zadeh Jafar plain located in tropical and arid southern of Kohgiloyeh province the distance of $5 \mathrm{~km}$ North East to Gachsaran sity is allocated to, with an average annual rainfall of $394 \mathrm{~mm}$ and an area of about 61 square kilometers is a part of the study area of imam zadedh Gafar. The necessity to provide drinking water for Gachsaran city by WWC and rural and agricultural development, drinking water is part of the village by the Water and Wastewater decreased ground water level in the years 1983 to1987 7.4 meter and change of water quality (Mahab 1985). This study aimed to evaluate the effect of artificial recharge of water spreading methods and ponds recharge, on the water table and Also investigating the Performance of MODFLOW model in the management and exploitation of groundwater in case study. Also the study of behavior of the imam zadeh jafar aquifer in various options such as more using from ground water and nutrition, and program management of water resources and to evaluate the effect of artificial recharge of on the aquifer plain groundwater of the most important objectives of this study is more important. . Figure 1 shows the location of the target region in Iran. 


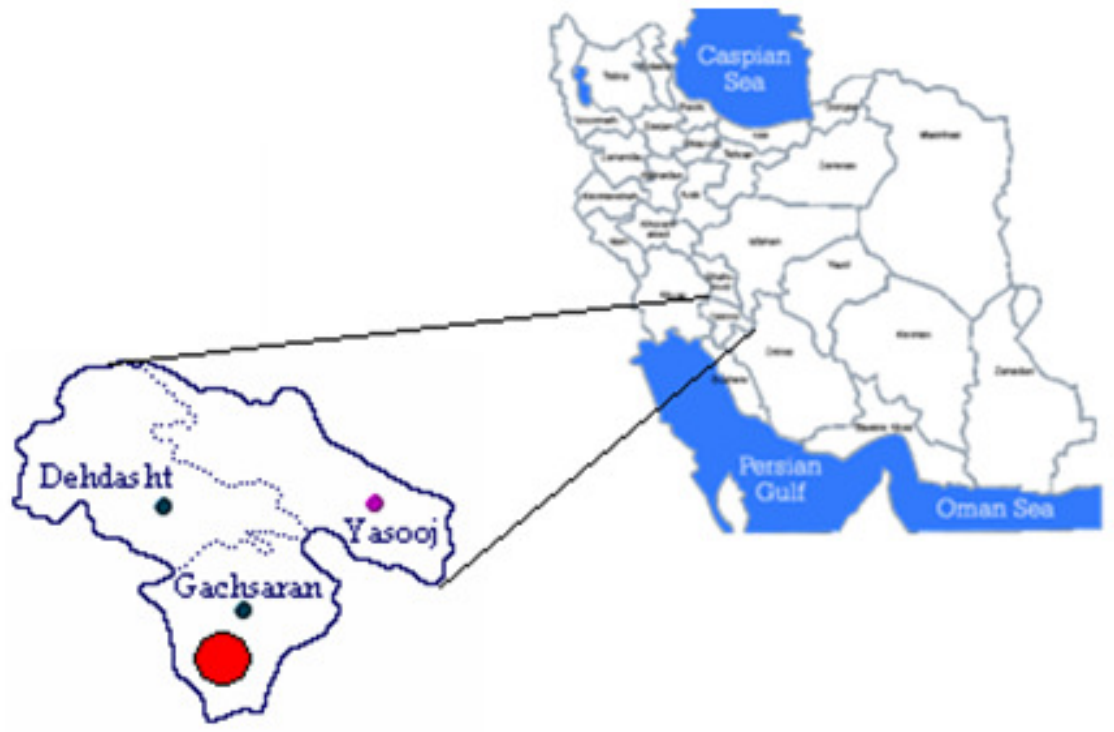

Figure 1. Location of the study area

\section{RESEARCH METHOD}

In general, started numerical methods, especially finite difference and finite elements for solving equations and transfer of 1950 the world and and various computer programs were writen and presented to solve the equations so far, many aquifers were analyzed by this method.Chang et al (1964) used of a simulation model on investigated several options to achieve the best state of the economy in a coastal area in Los Angeles, where the influx of salt water to fresh water and increasing the cost of groundwater extraction had created, general and administrative problems . Beckrose and Friend (2001) have been simulated groundwater flow and runoff effective on Avrvmvryn aquifer system in Canada.The history of modeling and simulation in Iran started since 1962, in Varamin plain. Kazemi, Golian 2003) has been simulated Shirvan plain in Ghoochan evaluated using MODFLOW 2000. Much of the needed information is available from archive of Kohgiluyeh \& Boyrahmad Regional Water Company which have been fixed directly in the field of control and defects. The required information includes groundwater level model, monthly measurements of water level observation wells, pumping wells factors hydrodynamics way using the results of exploration, exploitation of aquifers using inventory data across sources And water use, land surface topography data using topographic maps of 1: 250,000 and benchmarking observation wells plain, thick tablecloths and bed rock variations using geophysical studies drilling exploration wells ( 2 rings) has been simulated, around the aquifer through the map geological, geophysical, exploration drilling and field survey and information of rainfall and Temperature and evaporation and evaporation using rain gauge stations on the ground and adjacent areas of preparation, study and have been corrected. Finally required data for MODFLOW model collected and given as input to the model, the model was calibrated stable and unstable conditions And in different conditions aquifer to verify the under multiple conditions and recharge and discharge (tapping), simulated aquifer behavior and the effects of different options, were selected for optimum utilization.Therefore method has been with field units, library, software computing and information processing and different mapping. 


\section{GEOLOGY OF THE STUDY AREA}

Imam Zadeh Jafar plain located in the Zagros Fold of geological aspect geological structure of this plain is simple, light and compact and includes a set of strings of anticlines with trend northwest-SE axis usually vertical and east. Asmari and Gachsaran formations have most outcrops in the area and have the most important role in the organization boundaries of the plain model. Especially Asmari formation have the longest borders and is the most effective aquifer and make plain on the groundwater level (Figure 2) Geological map shown in Figure 3 Strike of the plain is northwest - southEast and trend of surface water flow in the same direction. The erosion of plain wrer producted by limestone upstream formations that in the area of plain and formed to young and old in the recently alluvial. . The ingredients of alluvium are along the often coarse alluvial fans and the type of stone, gravel, sand and clay plains in the central region and the exit region with an average particle size of clay and silt plains and usually fine.

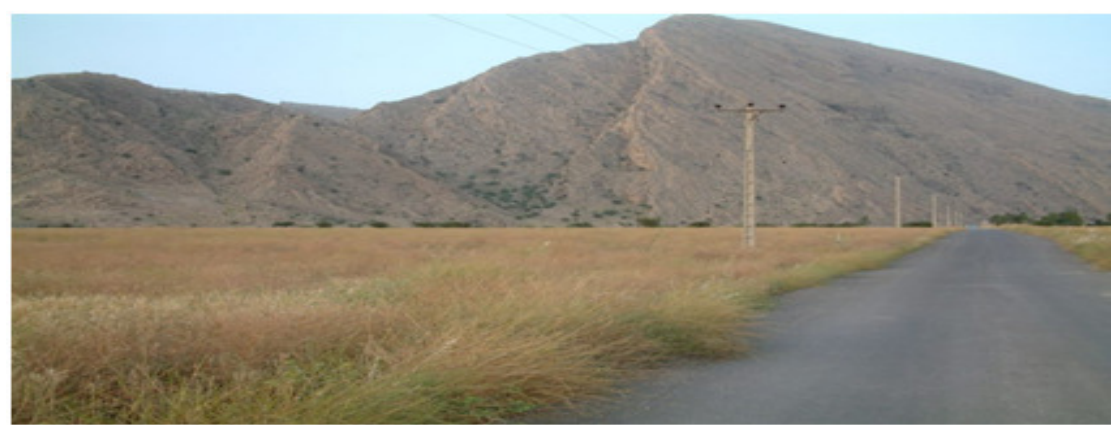

Figure 2: the outcrop of Asmari formation in north of plain

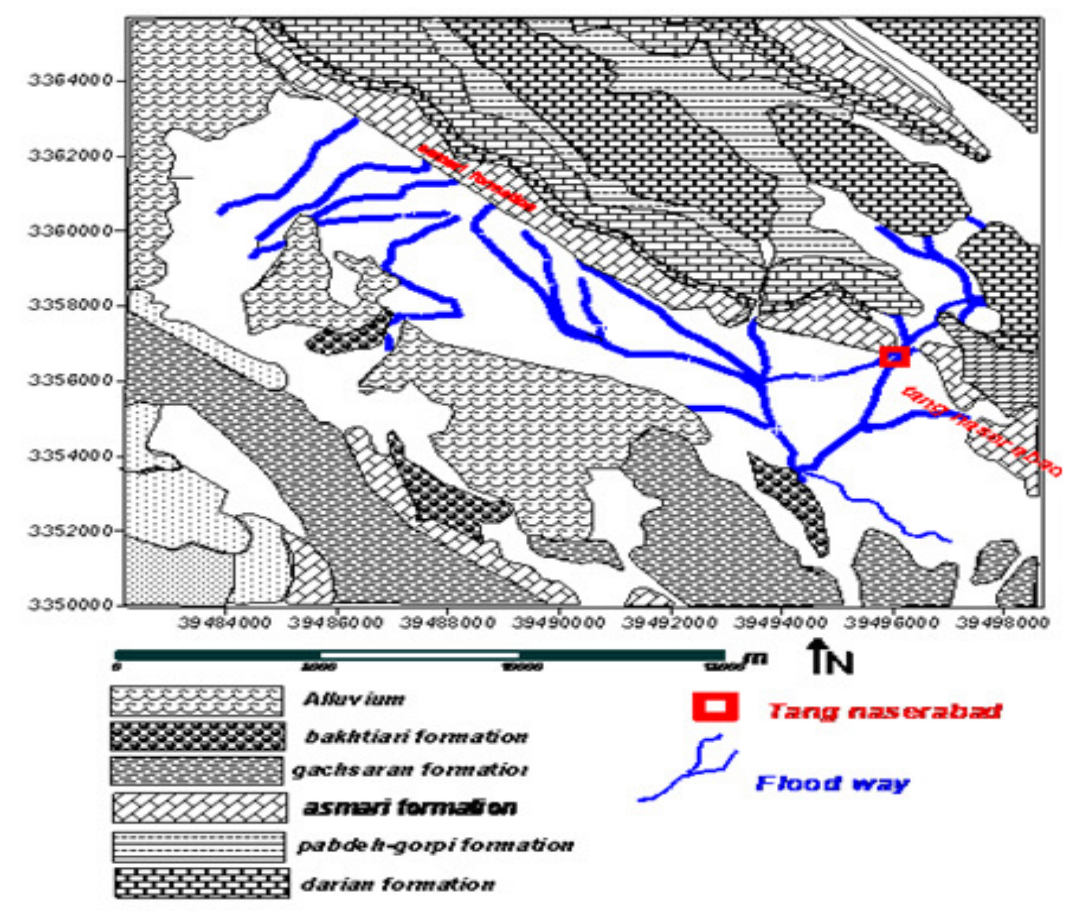

Figure 3. Geological map of the study area 
Advanced Medical Sciences: An International Journal (AMS), Vol 5, No.1, February 2018

\section{GEOPHYSICAL STUDIES}

Plain geophysical studies were performedin 1993 by Consulting Engineers jarfpoya co. geoelectric method. The project is probing to a depth of 250 meters in 10 sections 86 and takes the Earth's surface. The results of this work shows, unconfine of the aquifer and to determine the type of geological formation in the lower alluvial deposits according to their apparent specific resistance, the depth of bedrock that is variable 20 meters at the plain surface waters up to 220 meters in the central area. edrock of unconfine aquifer is Gachsaran formation, and in parts of the plain, limestone and conglomerate exotic of Asmari and Bakhtyari. Figures 4 and 5 show that the topography of bed rock and serface . study unit hydrograph (Figure 6) shows that the level of water in 76 to 82 downturn to size 5 meters and from 2004 to 2007 to size 23 meters raised water level of $05 / 1$ and $23 / 1$ meters.

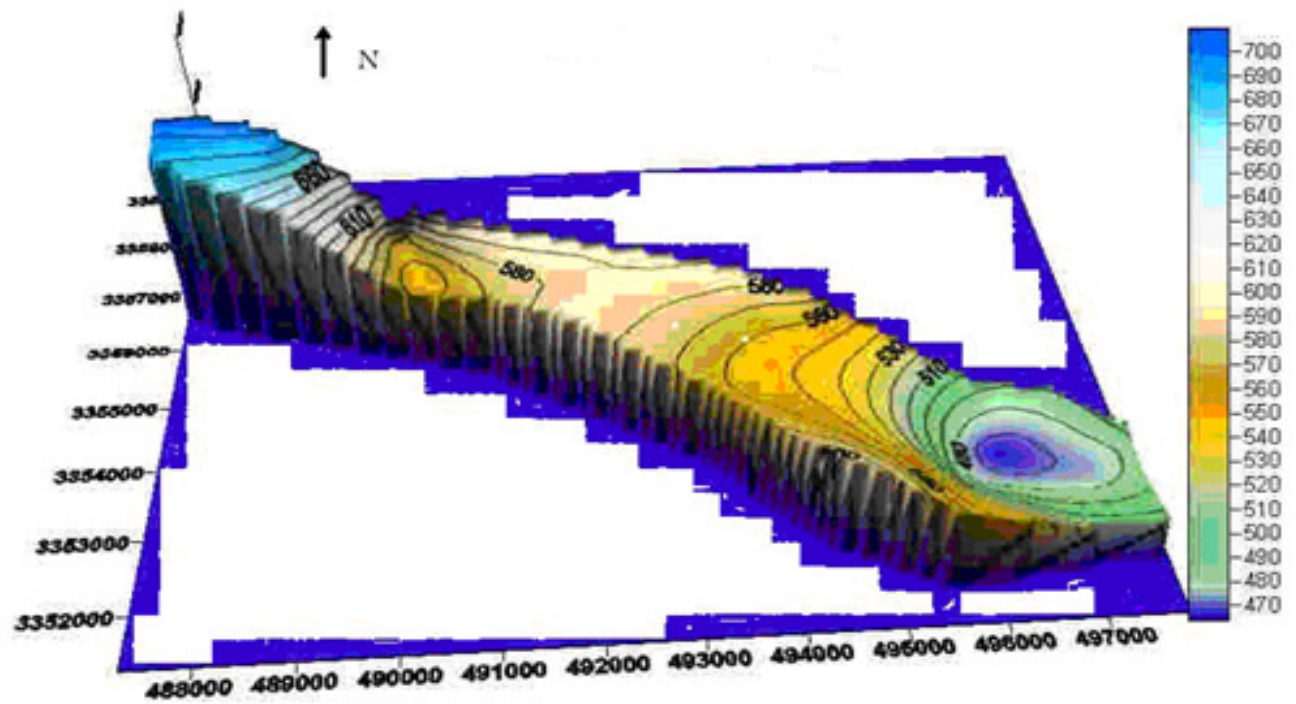

Figure 4. Topography of bed rock of imamzadeh jafar plain

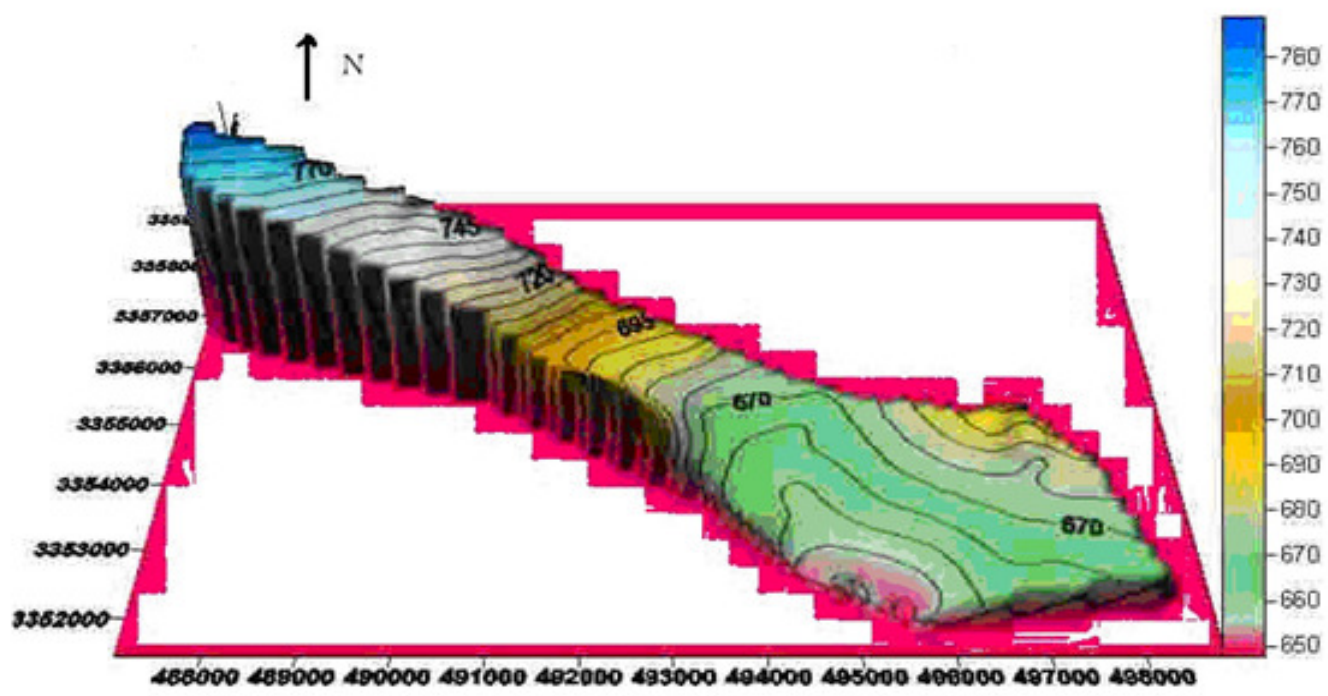

Figure 5. The topography of surface of imamzadeh Jafar plain 


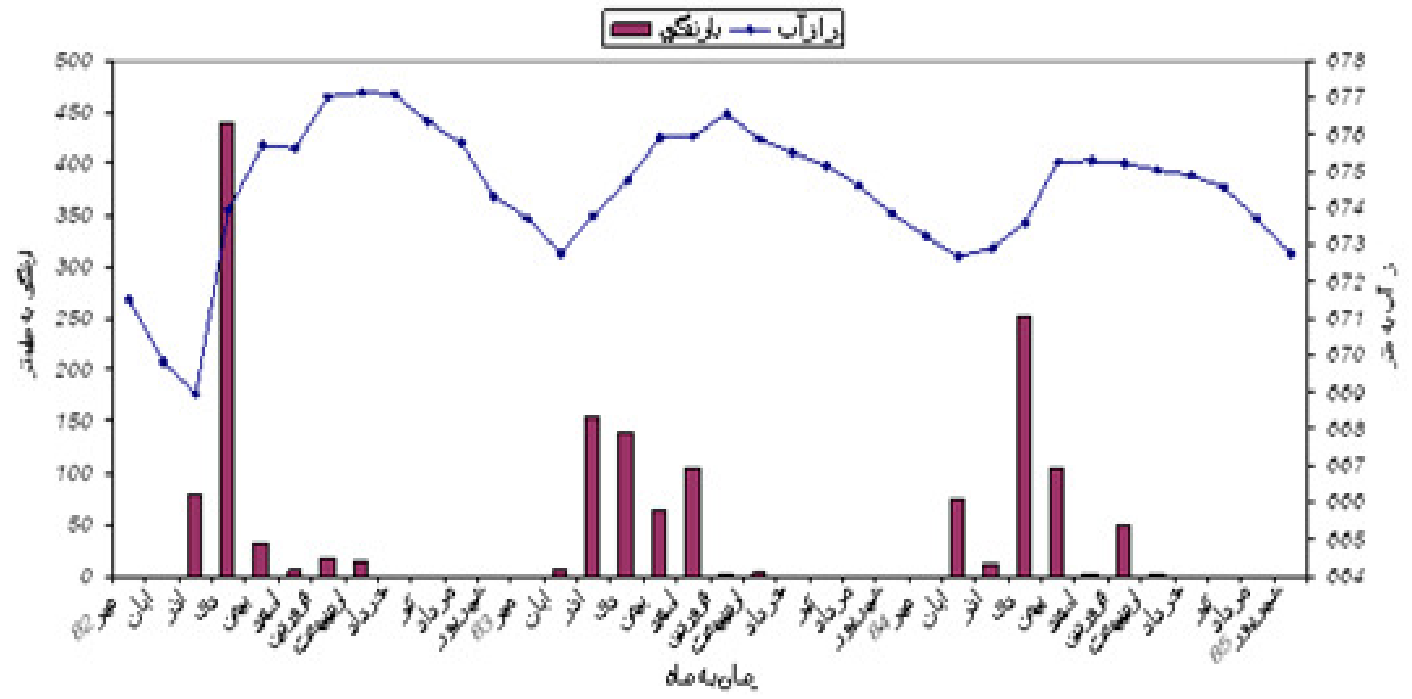

Figure 6 - unit hydrograph in 2004-2007

\section{DATA COLlection}

One of the most critical steps in modeling is, data collection and information and correcting them. Because the amount of numerical accuracy, depends on the quality and accuracy of data input and the ability to provide this data in its natural condition.in simulating of Imam zadeh Jafar aquifer have been used, from data observed and recorded a total of 18 wells . Location and harvest amount of groundwater resources determined and calculated using the national inventory report Abfan Consulting Engineers Water Resources 2003That Using the software package wells (wells) in Modflow for modeling given with negative number form. Data related to the earth's surface topography using topographic maps of 1: 250,000 and benchmarking observation wells were prepared and after grid software surfer moved to model Data related to the earth's surface topography were prepared using topographic maps of 1: 250,000 and benchmarking observation wells. The grid is moved. software surfer, the model bed rock of geophysical data have been used for mapping the plain and drilled exploration wells The results of exploration wells pumping test, used to determine the hydrodynamic coefficients table and table feeding rate after the budget calculation, the model is given Column grid rows 48 and 28 there was a total of 1344 cells In plain network of 1344 cells, 345 cells and 999 cells as active cells as the cells are considered inactive Figure 7 shows network built model, location and observation wells, exploitation, boundary conditions and network active and inactive cells The absence of an entire network with the appropriate number of wells observed piezometric accurate measurement of the level of the water table caused by natural boundaries do not match the boundaries of the range model is a balance way. Thus, the boundaries of the area covered obliged to comply wells have been observed. Use the map water level in the months of drought and wet years and the balance calibration model (2002-2003) groundwater inflow and outflow boundaries in 5 sections (two inlet and outlet section 3 ) have been determined (Figure 8). 
Advanced Medical Sciences: An International Journal (AMS), Vol 5, No.1, February 2018

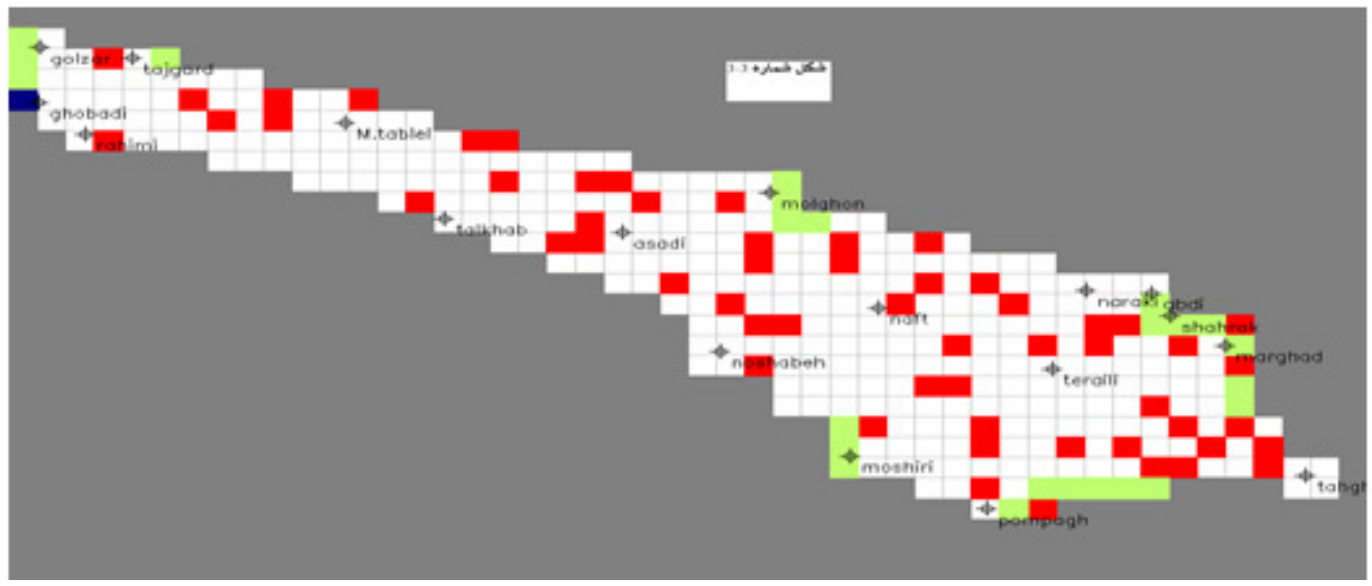

Figure 7. Mesh and location of observation wells and boundary conditions.

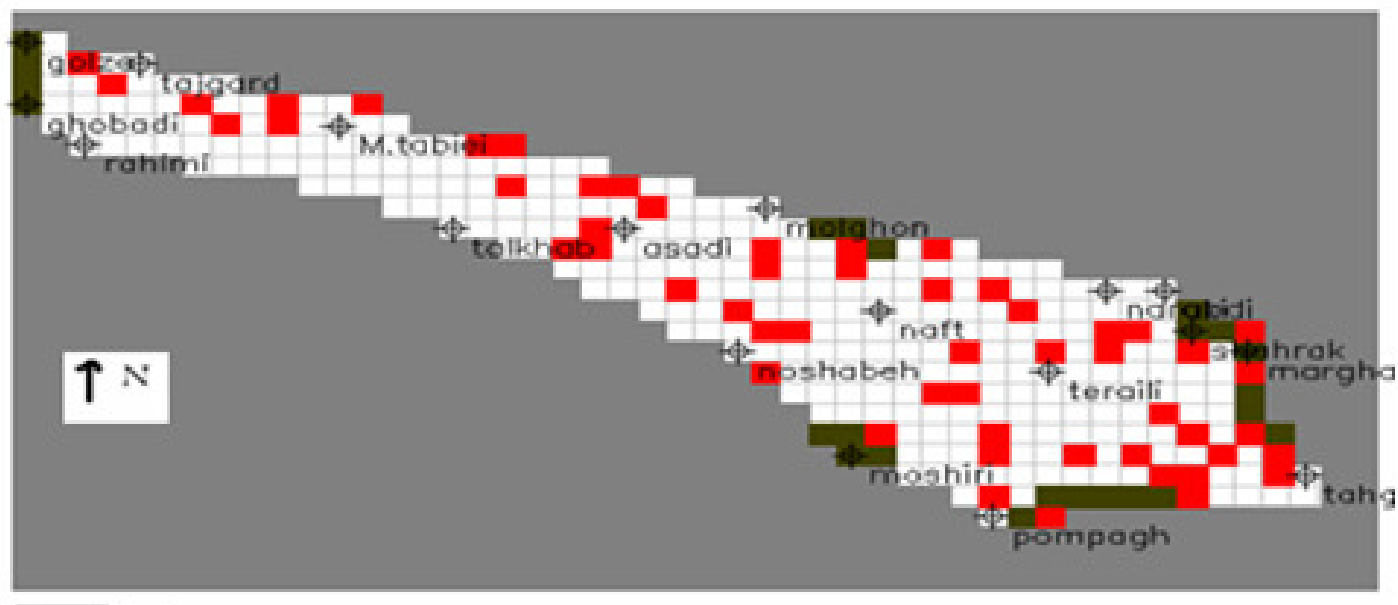

Figure 8. Boundaries input and output

\section{SPATIAl DATA MODEL}

This information includes the coordinates of each active cell such as aquifer surface topography and height of the stone floor. Since the aquifer is a free, The upper boundary of the aquifer layer to the surface of the Earth According to the observational benchmarking existing wells using existing elevation points on a topographic map of 1: 250,000, the number more than 120 points with UTM coordinates and elevation above sea level, networking and surfer by software interpolation up And elevation contour map drawing and the model is The average height of the center of each cell is shown in the model. Using data from observation wells and geophysical reports Plains (dynamic deep Consulting Engineers), coordinates a number of points, by the use of software surfer and networking and interpolation methods in which the stone floor elevation map was produced and the model is transferred. 
Advanced Medical Sciences: An International Journal (AMS), Vol 5, No.1, February 2018

\section{MODEL VERIFICATION AND IMPLEMENTATION}

Verification of the model, true or false composition determines the parameters used in the model. In the period of testing, no change in the parameters of hydraulic conductivity and specific yield has not been established and there has been a change in the time-dependent variables. True measure of validation, calibration is similar. Time-dependent variables, including precipitation, and consequently the rate of aquifer recharge and the amount of water taken from the aquifer are. In order for the model to be examined in conjunction with hydraulic coefficients, the calibration and validation of 81-80 years to $85-84$ years was conducted. The results of this step are shown in Figures 3-28 numbers. As compared to the values measured or predicted by the model, in different piezometers indicate that the model has good ability. Figures were below 9 .
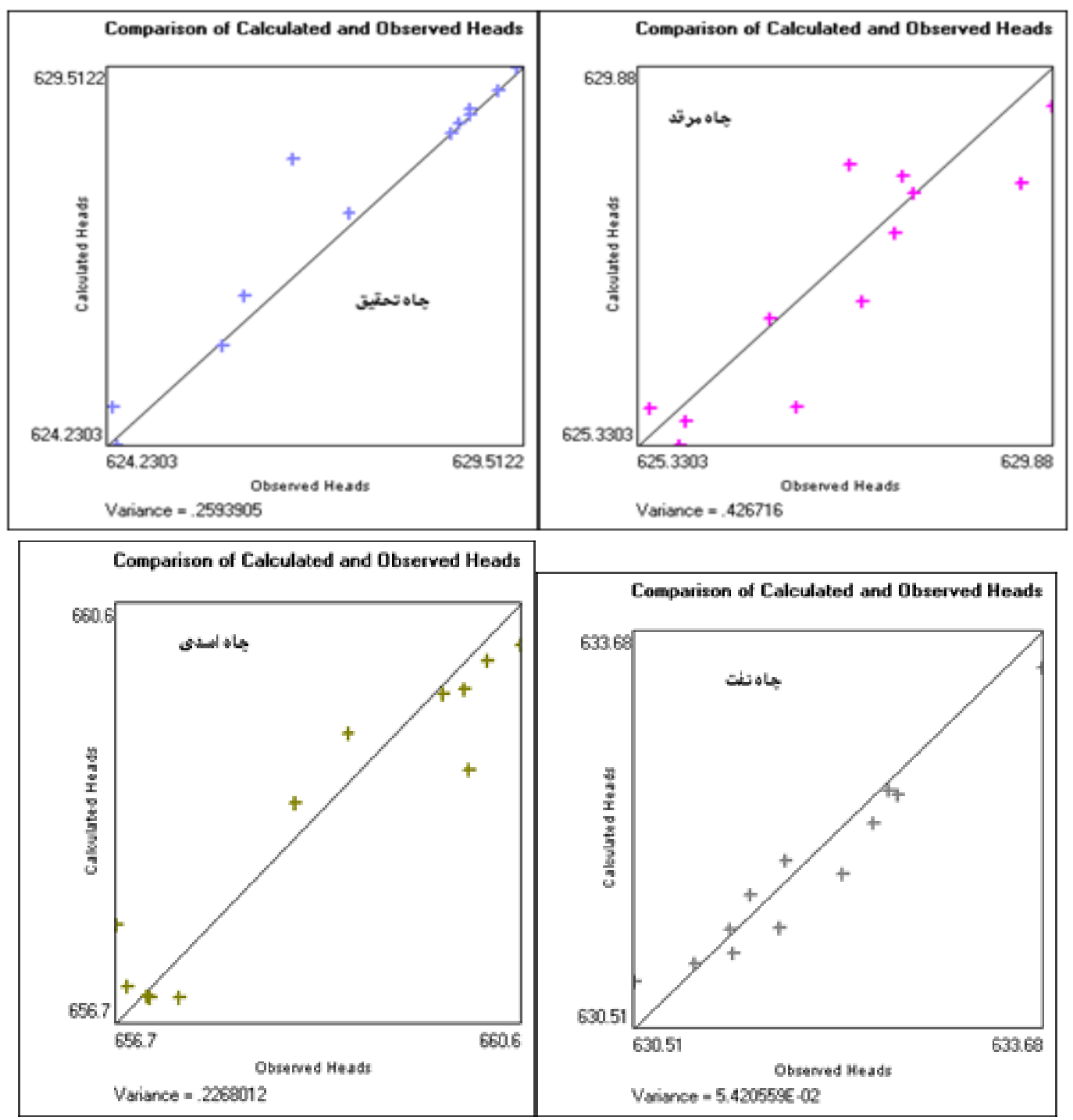

Figure 9. The results validate the model 
Advanced Medical Sciences: An International Journal (AMS), Vol 5, No.1, February 2018

In terms of commodities in tight Nasser artificial feeding, unit hydrograph increase in water level will form three meters (10).

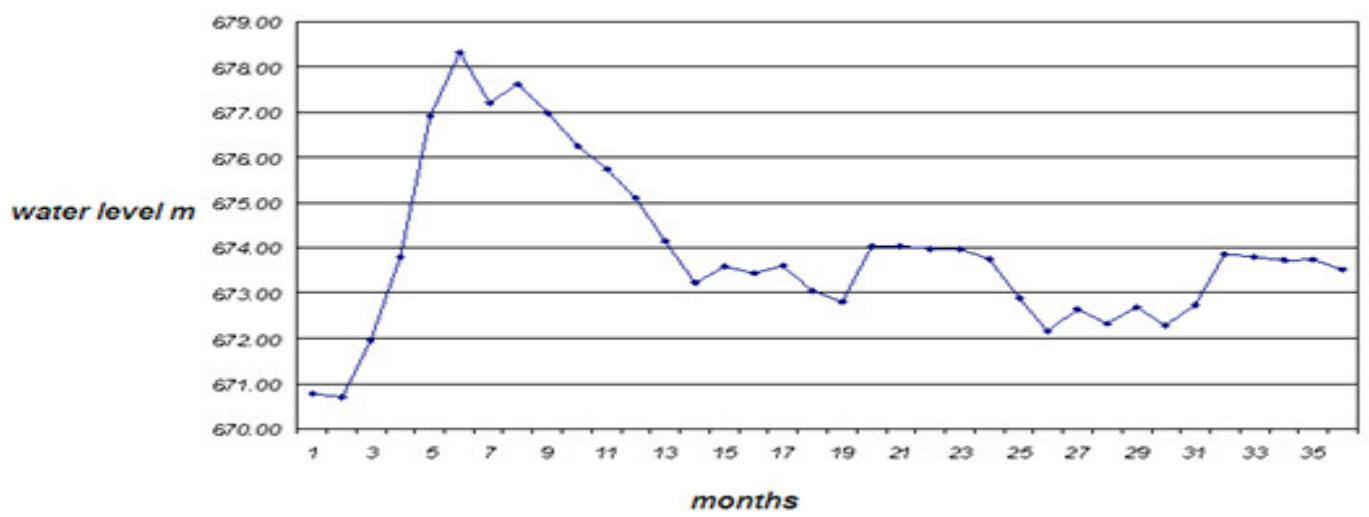

Figure 10. Water level changes with the implementation of artificial recharge of Tange Nasser

\section{CONClusion}

Due to the damage and side effects of decline in groundwater levels in alluvial aquifers, in the long run, even with artificial recharge of water, is not compensated, therefore is mainly applied and performance as follows:- Due to investments in projects of the pool, it is suggested to increase the permeability of layer-clearing tanks and ponds do Gyrd.- New interpretation or construction of any new project in this desert using the results of the model Gyrd.-Wells in the plain view of the lack of appropriate distribution at the outlet surface so plain, North West at least 6 wells drilled in the stone floor Grdd.- Scientific principles and existing exploration wells pumping tests to determine the alluvial aquifers hydrodynamic coefficients - Due to being a part of the groundwater to drinking oil company outside of the shrine Parsley and water is not returned to the table, Oil companies need to provide drinking water through the dam reservoir Amazadh J. Kosar and allocation of groundwater and drinking in certain circumstances it is recommended to industry.

\section{ACKNOWLEDGEMENTS}

I would like to thank research deputy of Islamic Azad university, Dehdasht branch for supporting

\section{REFERENCES}

[1] Anderson, MP, and W.W.Woessner (1992). Applied Ground Water Modeling _ simulation of flow and Adjective Transport. California: Academic Press, Inc. 381 PP.

[2] Abfan Consulting Engineers, 1381, the national inventory of water resources kohgiloyeh

[3] Alizadeh, A., 1382, the principles applied hydrology, Astan Quds Razavi

[4] Chen, X. H. \& Chen, X., 2003a, "Sensivity analysis and determination of stream bed leakage and aquifer hydraulic properties", J. Hydro., Vol. 284: 270-284. 
Advanced Medical Sciences: An International Journal (AMS), Vol 5, No.1, February 2018

[5] Kazemi Golian, r., 1381, "hydrogeological assessment and management of Shirvan, Quchan using numerical models Modflow _ 2000", master's theses, hydrology (hydrogeology), Shiraz University, $360 \mathrm{p}$.

[6] Chitsazan, M., 1381, fashion Lsazy groundwater, Shahid Chamran University Press, p. 366.

[7] Hill, M. C., F. A. D'Agnese, and C. C. Faunt, Guidelines for model calibration and application to simulation of flow in the Death Valley regional ground-water system, in Proceedings of the 1999 ModelCARE Conference, Zurich, Switzerland, September 1999, edited by F. Stauffer et al., IAHS Publ., 265, 195-204, 1999.

[8] Regional Water Organization of Fars, Bushehr and Kohgiluyeh, 1373, Report of artificial recharge projects Naserbad Gachsaran

[9] The National Cartographic, 1375, topographic map of Iran - PA with a scale of 1: 25000.

[10] McLaughlin, D., and E. F. Wood, A distributed parameter approach for evaluating the accuracy of groundwater model predictions, 2, Application to groundwater flow, Water Resour. Res., 24(7), 1048-1060, 1988.

[11] Sun, N.-Z., and W. W.-G Yeh, Coupled inverse problems in groundwater modeling, 2, Identifiability and experimental design, Water Resour. Res., 26(10), 2527-2540, 1990

[12] National Iranian Oil Company, 1996, Gachsaran geological map at a scale of 1: 100,000

[13] The dynamic deep Consulting Engineers, 1382, Report on the plains of artificial recharge Shrine J.. Mahab Consulting Engineers, 1365 and 1367, Report on water supply and irrigation Jafar Zadeh

[14] Wang, H.F., Anderson, M.P., 1992.Introduction to groundwater modeling. an Faransisco.pp.519-524

[15] Wagner, B. J., Evaluating data worth for ground-water management under uncertainty, J. Water Resour. Plann. Manage., 125(5), 281-288, 1999.

[16] Wagner, B. J., Sampling design methods for groundwater modeling under uncertainty, Water Resour. Res., 31(10), 2581-2591, 1995.

\section{AUTHOR}

Email: kh_shafieimotlaq@yahoo.com

$\mathrm{PhD}$ in Water Resources

Civil and Science Department, Faculty member of engineering and technical, Islamic Azad University, Dehdasht Branch, Dehdasht (Iran)

Ph:07432261628 - 0743228939

Fax: 07443228939

Mobile: 09173424223

Khosrow Shafiei Motlagh- Born in 1974- Zargham Abad- Dehdasht - Iran Faculty member of Islamic Azad University Dehdasht Branch- Dehdasht- Iran Diploma: Empirical Sciences - Shahid Beheshti high school -Dehdasht- Iran

Associate: Empirical Sciences - Izadpanah Teacher trainnningigYasouj- Iran

- Bachelor: Applied Geology - Shahid Chamran university- Ahwaz - Iran

- Master's Degree: (Groundwater) - Zahedan - Iran

- Ph.D. of Water Resources Engineering- Tehran University of Science and Research -Tehran- Iran

- Judicial expert in water engineering- yasuj- iran

- Member of Mining Engineering Organization of Kohgiluyeh and Boerahmad Province- iran

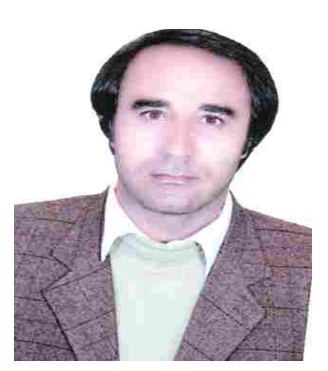

